\title{
PENGEMBANGAN E-LEARNING MENGGUNAKAN SCHOOLOGY PADA MATA PELAJARAN MESIN KONVERSI ENERGI
}

\author{
Ratih Danu Warso', Julaga Situmorang 2 , R. Mursid ${ }^{3}$ \\ ${ }^{1}$ Sekolah Menengah Kejuruan Negeri 2 Tanjungbalai, Sumatera Utara \\ ${ }^{2,3}$ Pascasarjana Universitas Negeri Medan \\ danuwarso85@gmail.com ${ }^{1}$
}

\begin{abstract}
Abstrak : Studi ini bertujuan menghasilkan sebuah produk media pembelajaran berbasis e-learning yang layak digunakan dan efektif, mudah dipelajari siswa dan dapat dipakai untuk pembelajaran individual. Jenis penelitian ini adalah penelitian pengembangan yang menggunakan model pengembangan produk Brog dan Gall yang dipadu dengan model pengembangan pembelajaran Dick and Carey.. Data kualitas produk pengembagan ini dikumpulkan dengan angket. Data-data yang dikumpulkan dianalisis dengan teknik analisis data deskriptif kualitatif. Hasil penelitian menunjukkan : (1) uji materi mesin konversi energi berada pada kualifikasi sangat baik (93,83\%), (2) uji ahli desain pembelajaran berada pada kualifikasi sangat baik (88,55\%), (3) uji rekayasa perangkat lunak berada pada kualifikasi sangat baik (94,10\%), (4) uji coba perorangan berada pada kualifikasi sangat baik (91,43\%), (5) uji coba kelompok kecil berada pada kualifikasi sangat baik (93,63\%), (6) uji coba lapangan berada pada kualifikasi sangat baik (97,96\%). Dari hasil efektifitas produk pemebelajaran media e-learning menggunakan schoology yaitu rata-rata nilai siswa sebesar 80,46\% dibandingkan dengan siswa tidak menggunakan media e-learning menggunakan schoology sebesar 71,71\%. Disimpulkan macromedia flash mesin konversi energi berbasis schoology layak digunakan dan efektif bagi siswa dan guru karena rata-rata uji coba produk mencapai 93,25\% dalam kriteria sangat baik
\end{abstract}

Kata kunci : macromedia flash, mesin konversi energi, e-learning schoology

\begin{abstract}
This study aims to produce a media product based learning e-learning proper use and effective, easy to learn and can be used for the students' individual learning. This type of research is the development of research that uses models and Gall Brog product development combined with the development of learning models Dick and Carey. This learning product development model is a model that is prepared in a programmed sequence of systematic and meet the characteristics of the students in learning.. Pengembagan product quality data is collected by questionnaire. The data collected were analyzed with descriptive qualitative data analysis techniques. The results showed: (1) judicial review of energy conversion machines are in excellent qualifications (93.83\%), (2) test instructional design experts are in excellent qualifications (88.55\%), (3) test software engineering are in excellent qualifications (94.10\%), (4) individual testing are in excellent qualifications (91.43\%), (5) small group trial are in excellent qualifications (93.63\%), (6) field trials are in excellent qualifications (97.96\%). From the results of product effectiveness pemebelajaran media e-learning using Schoology which is the average value of students amounted to $80.46 \%$ as compared to students not using e-learning media use Schoology amounted to 71.71\%. Concluded Macromedia Flashbased energy conversion machines used Schoology feasible and effective for students and teachers as the average trial products reached $93.25 \%$ in the criteria very well
\end{abstract}

Keywords : macromedia flash, energy conversion engineering, e-learning schoology

\section{PENDAHULUAN}

Pendidikan merupakan salah satu aspek kehidupan yang sangat vital dan fundamental karena pendidikan memiliki peran yang amat penting dalam menentukan aspek-aspek kehidupan lainnya. Oleh karena itu, pengelolaan pendidikan perlu memperoleh prioritas dan perhatian yang serius oleh segenap pemangku kepentingan pendidikan, dan bukan hanya tanggung jawab pemerintah semata. Pendidikan nasional bertujuan untuk mengembangkan potensi peserta didik agar menjadi manusia yang beriman dan bertakwa kepada Tuhan Yang Maha Esa, berakhlak mulia, sehat, berilmu, cakap, kreatif, mandiri dan menjadi warga negara yang demokratis serta bertanggung jawab (Permendiknas No. 20 Tahun 2003). Pendidikan merupakan salah satu bentuk perwujudan kebudayaan manusia yang dinamis. Oleh karena itu perubahan dan perkembangan pendidikan menjadi sesuatu yang seharusnya terjadi sejalan dengan 
perubahan budaya kehidupan. Perubahan dalam arti perbaikan mutu pendidikan pada semua tingkat perlu terus menerus dilakukan sebagai antisipasi kepentingan masa depan. Berdasarkan hal ini maka peran guru menjadi kunci sukses keberhasilan dalam mencapai tujuan pendidikan dan tujuan pembelajaran di sekolah.

Proses pembelajaran itu sendiri merupakan sebuah sistem yang di dalamnya terdapat berbagai komponen yang saling bekerja sama dan terpadu untuk mencapai tujuan pembelajaran. Komponen-komponen tersebut adalah tujuan pengajaran, guru dan peserta didik, bahan pengajaran, metode dan strategi belajar mengajar, alat atau media, sumber pelajaran dan evaluasi.

Sekolah Menengah Kejuruan (SMK) Negeri 2 Tanjungbalai adalah salah satu SMK yang memiliki fasilitas pembelajaran yang cukup memadai. Dari sarana dan prasarana yang tersedia dapat menunjang hasil belajar yang maksimal. Ini terbukti dengan beberapa fasilitas pembelajaran yang mendukung dari proses pembelajaran diantaranya ketersediaan infocus disetiap ruangan, fasilitas lab computer serta jaringan Wifi yang tersedia untuk membantu guru dan siswa dalam mencari ilmu pengetahuan yang baru. Namun pada kenyataannya fasilitas yang tersedia tidak mendorong untuk mendapatkan hasil belajar siswa yang maksimal. Ini terlihat dari masih rendahnya.

Pemanfaatan e-Learning menjadi salah satu solusi terhadap kesenjangan akses pendidikan yang memarginalkan masyarakat yang berada di luar Pulau Jawa sehingga anggota masyarakat bisa menikmati pendidikan, baik yang diselenggarakan secara tatap muka (konvensional) maupun secara modern yang salah satunya dilaksanakan melalui pemanfaatan internet. Hal yang sama diungkapkan oleh Soekartawi (2007:4) bahwa “... e-Learning memang sangat membantu menyelesaikan masalah pendidikan yang menyangkut upaya meningkatkan pemerataan dan akses pendidikan".

Belajar juga unsur yang sangat mendasar dalam penyelenggaraan setiap jenis dan jenjang pendidikan yang ditempuh seseorang untuk memperoleh pengetahuan. Pemahaman tentang arti belajar sangat diperlukan oleh para pendidik, agar membantu pencapaian hasil belajar siwa yang berkualitas. Hamalik (2003:31), menyatakan bahwa belajar mengandung pengertian terjadinya perubahan dari persepsi dan prilaku, termasuk juga perbaikan prilaku, misalnya pemuasan kebutuhan masyarakat dan pribadi secara lengkap.. Kingsley (dalam Ahmadi dan Supriono 2008:127), Learning is the by which behavior in the broader sense is originated or changed through practice or training. Diartikan belajar adalah proses dimana tingkah laku (dalam arti luas) ditimbulkan atau diubah melalui praktek atau latihan. Selanjutnya Meyer, Smith \& Ragan (dalam Pribadi, 2009:4), belajar sebagai perubahan yang relatif permanen dalam pengetahuan dan perilaku seseorang yang diakibatkan oleh pengalaman. Hakikat hasil belajar merupakan tindakan dan perilaku siswa yang kompleks. Siswa merupakan bagian dari faktor penentu terjadinya proses pembelajaran yang efektif dan efisien.

Aktivitas belajar siswa merupakan dorongan dari rasa keingintahuan dan merupakan kebutuhan saat itu. Reigeluth (1983:25), secara umum mengkatagorikan indikator keberhasilan siswa dalam belajar terdiri dari tiga hal yaitu: (1) efektivitas pembelajaran (effectiveness), yang biasanya diukur dari tingkat keberhasilan siswa dalam berbagai hal, (2) efisiensi pembelajaran (efficiency), yag biasanya diukur dari waktu dan pembiayaan, dan (3) daya tarik pembelajaran (appeal), yang selalu diukur dari tendensi siswa untuk belajar secara terus menerus.

Teknologi pembelajaran ialah teori dan praktek desain, pengembangan, pemanfaatan, manajemen, dan evaluasi proses dan sumberdaya belajar. Pada definisi ini teori terdiri dari konsep, konstruk, prinsip, dan proposisi yang memberi sumbangan terhadap body of knowledge (Seels \& Richey, 1994:78).

Reigeluth (dalam Mustaji 2012), mendefinisikan teori sebagai sekelompok prinsip yang secara sistematis diintegrasikan atau dimaksudkan untuk menjelaskan, memprediksi fenomena pembelajaran. Dengan demikian, teori-teori yang harus dimiliki oleh bidang Teknologi Pembelajaran (TP) untuk mendukung praktek disusun dengan tujuan utama menjelaskan dan memprediksi fenomena pembelajaran.

Association for Educational Communications Technology (AECT, 1977:1), mendefinisikan Teknologi pendidikan adalah proses kompleks yang terintegrasi meliputi: orang, prosedur, gagasan, sarana dan organisasi 
untuk menganalisis masalah dan merancang, melaksanakan, menilai dan mengelolah pemecahan masalah dalam segala aspek belajar pada manusia. Dari definisi tahun 1977 menggunakan istilah teknologi pendidikan dan berorientasi kepada teori dan praktek. Defenisi AECT 1994 dalam (Seels \& Richey 1994:1), "Instructional technology is the theory and practice of design, development utilization, management and evaluation of processes and resources for learning" yang artinya Teknologi Pembelajaran adalah teori dan praktek dalam desain, pengembangan, pemanfaatan, pengelolaan, serta evaluasi tentang proses dan sumber untuk belajar.

Terminologi e-Learning sendiri dapat mengacu pada semua kegiatan pelatihan yang menggunakan media elektronik atau teknologi informasi. e-Learning merupakan singkatan dari electronic learning, kata ini terdiri dari huruf "e"(electronic = elektronika) dan "learning" (pembelajaran). Jadi e-Learning berarti pembelajaran dengan menggunakan bantuan perangkat elektronika. e-Learning dapat melibatkan audio atau video-tapes, $\mathrm{CD}$ ROM dan DVD, video conferencing, e-mail, live chat, pemakaian web dan akhir-akhir ini mempergunakan mobile content.

Learn Frame (2000:18) menjelaskan bahwa e-Learning memiliki berbagai macam definisi, setelah dikelompokkan dari beberapa para ahli maka definisi e-Learning berdasarkan Schank (1997); Masie (1997); Carpenter-Smith (1999); HRD Canada (1999); Block \& Dobell (1999); Peterson et. all (1999) Urdan \& Weggen (2000) Gay \& Bacon (2000); Goldman Sarchs (2000) di antaranya: (1) E-Learning encompasses any form of learning transacted by way of digital technologies; (2) E-Learning delivery systems are subject to the dynamics of sociotechnological evolution.; (3) E-Learning may be synchronous or asynchrouous, selfpaced or instructorled, a process or a single event, online or offline, or any combination of these modes.

Jadi, e-Learning mencangkup berbagai macam transfer pengetahuan melalui teknologi digital, evolusi sosio-teknologi dengan cara pengiriman materi belajar secara dinamis, dan e-Learning dapat dilaksanakan pada waktu yang sama (synchorous) ataupun tidak pada waktu yang bersamaan (asynchronous), on-line maupun off-line ataupun kombinasi dari itu

Menurut Munir (2010: 202), istilah elearning memiliki definisi yang sangat luas.
Terminologi e-learning cukup banyak dikemukakan dalam berbagai sudut pandang, namun pada dasarnya mengarah pada pengertian yang sama. Huruf e pada e-learning berarti elektronik yang kerap disepadankan dengan kata virtual (maya) atau distance (jarak). Dari hal ini kemudian muncul istilah virtual learning (pembelajaran di dunia maya) atau Distance learning (pembelajaran jarak jauh). Sedangkan kata learning sering diartikan dengan belajar pendidikan (education) atau pelatihan (training).

Schoology adalah website yang memadu e-learning dan jejaring sosial. Konsepnya sama seperti Schoology, namun dalam hal e-learning schoology mempunyai banyak kelebihan. Membangun e-learning dengan schoology juga lebih menguntungkan bila dibanding menggunakan moodle yaitu karena tidak memerlukan hosting dan pengelolaan schoology (lebih user friendly). Tentu fiturnya tidak selengkap moodle, namun untuk pembelajaran online di sekolah sudah sangat memadai. Adapun fitur-fitur yang dimiliki oleh Schoology adalah sebagai berikut: Courses, Group Discussion, Resources, Quiz, Attendance dan Analytics.

Media apabila dipahami secara garis besar adalah manusia, materi atau kejadian yang membangun suatu kondisi yang membuat siswa mampu memperoleh pengetahuan, keterampilan atau sikap. Definisi lain, bahwa media merupakan alat yang digunakan untuk menyalurkan pesan atau informasi dari pengirim kepada penerima pesan (Pupuh, 2007: $65)$.

Gagne (2003:98), menyatakan bahwa media adalah berbagai jenis komponen dalam lingkungan siswa yang dapat merangsan siswa untuk belajar. Sedangkan menurut Anderson, media pembelajaran adalah media yang memungkinkan terwujudnya hubungan langsung antara karya seseorang pengembang mata pelajaran dengan para siswa (Musfiqon, 2012: 27).

Lebih lanjut Musfiqon (2012: 28), mengemukakan bahwa media pembelajaran dapat didefinisikan alat bantu berupa fisik maupun nonfisik yang sengaja digunakan sebagai perantara antara guru dan siswa dalam memahami materi pembelajaran agar lebih efektif dan efisien. Sehingga materi pembelajaran lebih cepat diterima siswa dengan utuh serta menarik minat siswa untuk belajar lebih lanjut. Pendek kata, media merupakan alat 
bantu yang digunakan guru dengan desain yang disesuaikan untuk meningkatkan kualitas

\section{METODE}

Metode penelitian yang digunakan adalah research and development, karena penelitian ini termasuk penelitian pengembangan pendidikan yang dimaksudkan untuk menghasilkan produk pembelajaran yang layak dimanfaatkan dan sesuai kebutuhan. Borg \& Gall (2005) memberikan batasan tentang penelitian pengembangan sebagai usaha untuk mengembangkan dan memvalidasi produkproduk yang digunakan dalam pendidikan. Adapun langkah-langkah dari tahapan pengembangannya adalah sebagai berikut :

1. Melakukan penelitian pendahuluan, yang meliputi:

a. Identifikasi kebutuhan pembelajaran dan menentukan standar kompetensi mata pelajaran.

b. Melakukan analisis pembelajaran.

c. Mengidentifikasi karakteritik dan perilaku awal siswa.

d. Menulis kompetensi dasar dan indikatornya.

e. Menulis tes acuan patokan.

f. Menyusun strategi pembelajaran yang diwujudkan dalam bentuk silabus dan satuan pembelajaran.

g. Mengembangkan materi pembelajaran.

2. Pembuatan desain software, yang meliputi: pembelajaran.

a. Pembuatan naskah

b. Pembuatan storyboard

3. Mengembangkan dan membuat e-learning menggunakan schoology Pada Mata Pelajaran Mesin Konversi Energi.

4. Review dan uji coba produk.

Analisis data dalam penelitian ini menggunakan analisis deskriptif kuantitatif. Semua data yang terkumpul dianalisis dengan teknik statistik deskriptif yang secara kuantitatif dipisahkan menurut kategori untuk mempertajam penilaian dalam menarik kesimpulan. Data kualitatif yang berupa pernyataan sangat kurang baik, kurang baik, sedang, baik dan sangat baik diubah menjadi data kuantitatif dengan skala nilai 1 sampai 5 . Hasilnya dirata-rata dan digunakan untuk menilai kualitas software pembelajaran. Kriteria software akan dikonversikan menjadi nilai dengan skala lima menggunakan Skala Likert yang dianalisis secara deskriptif persentase dengan rumus sebagai berikut (Sugiyono, 2007):

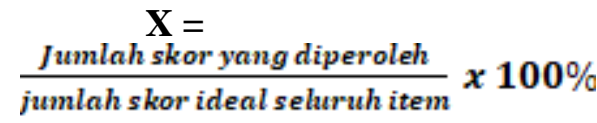

Dengan kriteria penilaian seperti yang tertulis pada tabel 1. berikut ini.

Table 1. Kriteria Penilaian

\begin{tabular}{|l|l|c|}
\hline Nilai & \multicolumn{1}{|c|}{ Kriteria } & Persentase \\
\hline A & Sangat baik & $80 \% \leq \mathrm{X} \leq 100 \%$ \\
\hline B & Baik & $60 \% \leq \mathrm{X}<80 \%$ \\
\hline C & Sedang & $40 \% \leq \mathrm{X}<60 \%$ \\
\hline D & Kurang baik & $20 \% \leq \mathrm{X}<40 \%$ \\
\hline E & Sangat kurang baik & $0 \% \leq \mathrm{X}<20 \%$ \\
\hline
\end{tabular}
$\mathrm{X}=$ Skor Empiris

\section{Teknik Analisis Data}

Dalam penelitian ini data yang diperoleh adalah hasil belajar siswa dari kelas eksperimen dan kelas kontrol. Teknik analisis data yang digunakan adalah teknik deskriptif dan Inferensial. Teknik deskriptif adalah statistik yang digunakan untuk menganalisis data dengan cara menggambarkan data yang telah terkumpul sebagaimana adanya tanpa bermaksud membuat kesimpulan yang berlaku untuk umum atau generalisasi. Misalnya penyajian data menggunakan table, grafik, diagram lingkaran, pictogram, perhitungan modus, median, mean, desil, persentil, rata-rata, standar defiasi, porsentasi, korelasi, dan regresi tanpa pengujian signifikasi. Dan teknik inferensial adalah teknik statistik untuk menganalisis data sampel data dan hasilnya diberlakukan untuk populasi. Suatu kesimpulan dari data sampel yang akan diberlakukan untuk populasi itu mempunyai peluang kesalahan dan kebenaran (kepercayaan). 
Langkah-langkah teknik analisa data sebagai berikut :

\section{Nilai rata-rata}

Untuk menentukan nilai rata-rata digunakan rumus :

$$
\bar{x}=\frac{\sum x_{i}}{n}
$$

(Sudjana, $2005: 67$ )

$$
\text { Dimana : } \begin{aligned}
\bar{x} & =\text { Rata-rata hitung } \\
\sum x_{i} & =\text { Jumlah semua harga } \mathrm{x} \\
\mathrm{n} \quad & =\text { Jumlah sampel }
\end{aligned}
$$

\section{Standar Deviasi}

Untuk menentukan Standar Deviasi digunakan rumus yaitu:

$$
s=\sqrt{\frac{\sum\left(x_{i}-\bar{x}\right)^{2}}{n-1}}
$$

(Sudjana, 2005: 93)

$$
\begin{array}{ll}
\text { Dimana: } & \mathrm{s}=\text { Standar Deviasi } \\
& \mathrm{x}_{\mathrm{i}}=\text { Harga data ke- } \mathrm{i} \\
& \mathrm{n}=\text { Jumlah sampel }
\end{array}
$$

\section{Uji Normalitas}

Uji normalitas data menggunakan teknik Lilliefors (Sudjana, 2005: 466). Langkahlangkah yang digunakan adalah sebagai berikut :

a. Data hasil belajar $\mathrm{x}_{1}, \mathrm{x}_{2}, \ldots \ldots, \mathrm{x}_{\mathrm{n}}$ dijadikan bilangan baku $\mathrm{z}_{1}, \mathrm{z}_{2}, \ldots \ldots, \mathrm{z}_{\mathrm{n}}$ dengan menggunakan rumus : $Z_{i}=\frac{X i-\bar{X}}{s}$

Dimana : $\quad \bar{x}=$ Nilai rata-rata hitung

$$
\mathrm{s}=\text { Simpangan baku. }
$$

b. Untuk tiap bilangan baku ini dan menggunakan daftar distribusi normal baku, kemudian dihitung pelunga $\mathrm{F}\left(\mathrm{z}_{\mathrm{i}}\right)=\mathrm{P}$ $\left(z \leq z_{i}\right)$.

c. Menghitung proporsi

$$
S\left(z_{i}\right)=\frac{\text { banyaknya } z_{1}, z_{2}, \ldots \ldots, z_{n} \leq z_{i}}{n}
$$

d. Hitung selisih $\mathrm{F}\left(\mathrm{z}_{\mathrm{i}}\right)-\mathrm{S}\left(\mathrm{z}_{\mathrm{i}}\right)$ kemudian tentukan harga mutlaknya.

e. Menentukan harga terbesar dari selisih harga mutlak $\mathrm{F}(\mathrm{Zi})$ - $\mathrm{S}(\mathrm{Zi})$ sebagai $\mathrm{L}_{\mathrm{o}}$. Untuk menerima atau menolak distribusi normal data penelitian dapat dibandingkan $\mathrm{L}_{\text {hitung }}$ dengan nilai kritis $\mathrm{L}_{\text {tabel }}$ yang diambil dari daftar tabel uji lilliefors dengan taraf $\alpha=5 \%$.
Kriteria pengujian :

Jika L $L_{\text {hitung }}<$ Ltable maka sampel berdistribusi normal.

Jika $\mathrm{L}_{\text {hitung }}>\mathrm{L}_{\text {table }}$ maka sampel tidak berdistribusi normal.

\section{Uji Homogenitas}

Uji homogenitas varians dihitung dengan menggunakan uji $\mathrm{F}$ yaitu:

$$
F=\frac{\text { VariansTerbesar }}{\text { VariansTerkecil }} \text { atau } F=\frac{S_{1}^{2}}{S_{2}^{2}}
$$

(Sudjana, $2005: 249$ )

Dimana :

$S_{1}^{2}=$ Varians dari kelompok yang lebih besar

$S_{2}^{2}=$ Varians dari kelompok kecil

Kriteria pengujian :

Jika $F_{\text {hitung }}<\mathrm{F}_{\text {tabel }}$ maka sampel mempunyai varians yang sama.

Jika $F_{\text {hitung }}>F_{\text {tabel }}$ maka sampel tidak mempunyai varians yang sama.

\section{Pengujian Hipotesis} adalah :

Hipotesis penelitian yang akan diuji

Ho $: \mu_{1}=\mu_{2}$

Ha: $\mu_{1}>\mu_{2}$

Keterangan :

$\mu_{1}=$ Rata-rata hasil belajar siswa yang diajar menggukan media e-learning menggunakan scholoogy

$\mu_{2}=$ Rata-rata hasil belajar siswa yang diajar dengan pembelajaran konvensional.

Ho $=$ Tidak ada perbedaan hasil belajar Mesin Konversi Energi siswa yang diajar dengan media e-learning menggunakan scholoogy lebih tinggi dari siswa yang diajar dengan pembelajaran konvensional.

$\mathrm{Ha}=$ Ada perbedaan hasil belajar Mesin Konversi Energi siswa yang diajar dengan media e-learning menggunakan scholoogy lebih tinggi dari siswa yang diajar dengan pembelajaran konvensional.

Untuk uji hipotesis digunakan rumus uji dua pihak : 


$$
t=\frac{\bar{x}_{1}-\bar{x}_{2}}{s \sqrt{\frac{1}{n_{1}}+\frac{1}{n_{2}}}}
$$

(Sudjana, $2005: 239$ )

Dimana $\mathrm{S}$ adalah akar varians gabungan yang dihitung dengan rumus :

$$
s^{2}=\frac{\left(n_{1}-1\right) s_{1}^{2}+\left(n_{2}-1\right) s_{2}^{2}}{n_{1}+n_{2}-2} \quad \text { Dimana }
$$

$S=\sqrt{S^{2}}$

Dimana :

$\mathrm{t}=$ Harga perhitungan

$\bar{x}_{1}=$ Skor rata-rata kelas eksperimen

$\bar{x}_{2}=$ Skor rata-rata kelas kontrol

$\mathrm{n}_{1}=$ Jumlah sampel kelas eksperimen

$\mathrm{n}_{2}=$ Jumlah sampel kelas kontrol

$s_{1}^{2}=$ Varians kelompok kelas eksperimen

$s_{2}^{2}=$ Varians kelompok kelas kontrol

$\mathrm{S}$ = Varians gabungan

Kriteria pengujian terima Ha jika $t_{\text {hitung }}$

$>\mathrm{t}_{\text {tabel }}$ yang didapat dari daftar distribusi $\mathrm{t}$ dengan dk $=(\mathrm{n}-1)$ dan taraf $\alpha=5 \%$.

Untuk melihat nilai keefektifan media pembelajaran interaktif yang dieksperimenkan digunakan rumus perhitungan efektifitas berikut (Sugiyono, 2007) :

$$
\mathrm{X}=\frac{\text { jumlah skor yang diperoleh }}{\text { jumlah skor ideal seluruh item }} \mathrm{X}
$$

$100 \%$

\section{HASIL DAN PEMBAHASAN \\ Hasil}

Proses pertama dalam kegiatan pengembangan ini adalah melakukan analisis kebutuhan di SMK Negeri 2 Tanjungbalai dengan cara menebar angket kepada 32 guru dan 58 siswa di program studi keahlian teknik kendaraan ringan tersebut dengan metode menguraikan defenisi dari media pembelajaran interaktif pada angket agar responden memiliki gambaran tentang pertanyaan dalam angket yang disampaikan. Hasil penelusuran dari angket yang disebar ditemukan bahwa $86 \%$ dari siswa menyatakan membutuhkan media elearning menggunakan schoology dalam proses pembelajaran agar proses pembelajaran berjalan lebih efektif, dan 93\% siswa menyatakan membutuhkan media e-learning menggunakan schoology agar dapat mereka jadikan sebagai sarana pembelajaran secara individual. Data analisis kebutuhan tersebut ditampilkan pada TabelBerdasarkan hasil angket analisis kebutuhan yang disebarkan oleh siswa dan siswa diperoleh kesimpulan sebagai berikut:

1. Sebagian besar guru maupun siswa (89\%) menyatakan belum mengenal media elearning menggunakan schoology dengan Macromedia Flash Professioanal 8.0 hanya sebagian kecil (7\%) guru dan siswa yang menyatakan telah mengenal media tersebut.

2. Sebagian besar (3\%) siswa menyatakan tidak menggunakan media e-learning menggunakan schoology dengan Macromedia Flash Professioanl 8.0 dalam proses pembelajaran dan seluruh siswa (93\%) menyatakan tidak pernah menggunakan media tersebut.

3. Sebagian besar siswa (86\%) menyatakan memerlukan media e-learning menggunakan schoology dalam proses pembelajaran dan seluruh siswa (100\%)

\begin{tabular}{|c|c|c|c|c|c|c|}
\hline \multirow{2}{*}{ No } & \multirow{2}{*}{ Jenis Informasi } & \multirow{2}{*}{ Jawaban } & \multicolumn{3}{|c|}{ Frekuensi } & \multirow{2}{*}{ Persentase } \\
\hline & & & Guru & Siswa & Jlh & \\
\hline 1. & $\begin{array}{l}\text { Telah Mengenal atau tidak mengenal } \\
\text { media e-learning menggunakan } \\
\text { schoology dengan Macromedia Flash } \\
\text { Professional } 8.0\end{array}$ & $\begin{array}{l}\text { Ya } \\
\text { Tidak }\end{array}$ & $\begin{array}{c}2 \\
30\end{array}$ & $\begin{array}{c}5 \\
53\end{array}$ & $\begin{array}{c}7 \\
89\end{array}$ & $\begin{array}{c}7,00 \% \\
89,00 \%\end{array}$ \\
\hline 2. & $\begin{array}{l}\text { Menggunakan atau tidak menggunakan } \\
\text { media e-learning menggunakan } \\
\text { schoology dalam proses pembelajaran }\end{array}$ & $\begin{array}{l}\text { Ya } \\
\text { Tidak }\end{array}$ & $\begin{array}{c}3 \\
29\end{array}$ & $\begin{array}{c}0 \\
58\end{array}$ & $\begin{array}{c}3 \\
93\end{array}$ & $\begin{array}{c}3,00 \% \\
93,00 \%\end{array}$ \\
\hline 3 & $\begin{array}{l}\text { Memerlukan atau tidak memerlukan } \\
\text { media e-learning menggunakan } \\
\text { schoology dalam prose pembelajaran }\end{array}$ & $\begin{array}{l}\text { Ya } \\
\text { Tidak }\end{array}$ & $\begin{array}{c}28 \\
4\end{array}$ & $\begin{array}{c}58 \\
0\end{array}$ & $\begin{array}{c}86 \\
4\end{array}$ & $\begin{array}{c}86,00 \% \\
4,00 \%\end{array}$ \\
\hline
\end{tabular}
menyatakan memerlukannya.

Tabel 2. Data Analisis Kebutuhan 
Uji coba lapangan teridiri dari 58 siswa dari dua kelas yaknik kelas TKR1 sebanyak 29 siswa dan kelas TKR2sebanyak 29 siswa. Uji coba lapangan menghasilkan data-data yang nantinya akan mengukur keBaikan dari produk yang dikembangkan, serta untuk mengetahui bagaimana manfaat produk tersebut bagi pemakainya. Hasil evaluasi terhadap media pembelajaran pada aspek kualitas materi pembelajaran dapat dilihat pada tabel pada Tabel 3.

Tabel 3. menunjukkan hasil tanggapan siswa pada aspek kualitas materi pembelajaran untuk uji coba lapangan keseluruhannya dalam kriteria "Sangat Baik"

Tabel 3. Skor Penilaian Media E-learning menggunakan schoology Mesin konversi energi Uji Coba Lapangan Pada Aspek Kualitas Materi Pembelajaran

\begin{tabular}{|c|l|c|c|c|c|c|c|c|}
\hline \multirow{2}{*}{ No } & \multicolumn{1}{|c|}{ Indikator Penilaian } & \multicolumn{5}{c|}{ Skor } & \multirow{2}{*}{ Rata-rata } & \multirow{2}{*}{ Kriteria } \\
\cline { 3 - 8 } & & $\mathbf{1}$ & $\mathbf{2}$ & $\mathbf{3}$ & $\mathbf{4}$ & $\mathbf{5}$ & & \\
\hline 1 & Kesesuaian materi & & & & 6 & 52 & $97,93 \%$ & Sangat Baik \\
\hline 2 & Kejelasan petunjuk belajar & & & & 3 & 55 & $98,97 \%$ & Sangat Baik \\
\hline 3 & $\begin{array}{l}\text { Kemudahan memahami kalimat pada } \\
\text { teks }\end{array}$ & & & 13 & 45 & $95,52 \%$ & Sangat Baik \\
\hline 4 & Kemudahan memahami pembelajaran & & & & 10 & 48 & $96,55 \%$ & Sangat Baik \\
\hline 5 & Ketepatan urutan penyajian & & & & 5 & 53 & $98,28 \%$ & Sangat Baik \\
\hline 6 & Kecukupan latihan & & & 13 & 45 & $95,52 \%$ & Sangat Baik \\
\hline 7 & Kejelasan umpan balik & & & & 58 & $100,00 \%$ & Sangat Baik \\
\hline 8 & Bantuan belajar dengan program & & & & 58 & $100,00 \%$ & Sangat Baik \\
\hline \multicolumn{2}{|c|}{ Rata-rata } & & & & $\mathbf{9 7 , 8 4 \%}$ & Sangat Baik \\
\hline
\end{tabular}

Hasil evaluasi terhadap media pembelajaran pada aspek kualitas teknis atau tampilan dapat dilihat pada tabel pada Tabel 4. Tabel 4 menunjukkan hasil tanggapan siswa pada aspek kualitas teknis atau tampilan untuk uji coba lapangan dan keseluruhannya dalam kriteria "Sangat Baik".

Tabel 4. Skor Penilaian Media E-learning menggunakan schoology Berbasis Komputer Pada Mata Pelajaran Konversi Energi Uji Coba Lapangan Pada Aspek Kualitas Teknis atau Tampilan

\begin{tabular}{|c|c|c|c|c|c|c|c|c|}
\hline \multirow{2}{*}{ No } & \multirow{2}{*}{ Indikator Penilaian } & \multicolumn{5}{|c|}{ Skor } & \multirow{2}{*}{ Rata-rata } & \multirow{2}{*}{ Kriteria } \\
\hline & & 1 & 2 & 3 & 4 & 5 & & \\
\hline 1 & Keindahan tampilan layar & & & & & 58 & $100,00 \%$ & Sangat Baik \\
\hline 2 & Keterbacaan teks & & & & & 58 & $100,00 \%$ & Sangat Baik \\
\hline 3 & Kualitas gambar dan animasi & & & & 5 & 53 & $98,28 \%$ & Sangat Baik \\
\hline 4 & Komposisi warna & & & & 15 & 43 & $94,83 \%$ & Sangat Baik \\
\hline 5 & Navigasi & & & & 9 & 49 & $96,90 \%$ & Sangat Baik \\
\hline 6 & Daya dukung music & & & & 8 & 50 & $97,24 \%$ & Sangat Baik \\
\hline 7 & Interaksi & & & & 2 & 56 & $99,31 \%$ & Sangat Baik \\
\hline \multicolumn{7}{|c|}{ Rata-rata } & $98,08 \%$ & Sangat Baik \\
\hline
\end{tabular}

Hasil penilaian uji coba lapangan terhadap aspek kualitas materi pembelajaran pada media e-learning menggunakan schoology pada mata pelajaran konversi energi dirangkum pada Tabel 4. Hasil tanggapan siswa pada Tabel 5. menyatakan bahwa untuk aspek kualitas materi pembelajaran pada uji coba lapangan menunjukkan 58 orang $(100,00 \%)$ menyatakan "Sangat Baik". 
Tabel 5. Tingkat Kecencerungan Penilaian Terhadap Aspek Kualitas Materi Pembelajaran Media E-learning menggunakan schoology Pada Mata Pelajaran Konversi Energi Pada Uji Coba Lapangan

\begin{tabular}{|c|l|c|c|c|}
\hline No & \multicolumn{1}{|c|}{ Kategorisasi } & Rentang Skor & Frekuensi & Persentase \\
\hline 1 & Sangat Baik & $81 \% \leq X \leq 100 \%$ & 58 & $100,00 \% \%$ \\
\hline 2 & Baik & $61 \% \leq X \leq 80 \%$ & 0 & $0,00 \%$ \\
\hline 3 & Sedang & $41 \% \leq X \leq 60 \%$ & 0 & $0,00 \%$ \\
\hline 4 & Kurang Baik & $21 \% \leq X \leq 40 \%$ & 0 & $0,00 \%$ \\
\hline 5 & Sangat kurang & $0 \% \leq X \leq 20 \%$ & 0 & $0,00 \%$ \\
\hline \multicolumn{2}{|r|}{ Jumlah } & $\mathbf{5 8}$ & $\mathbf{1 0 0 , 0 0 \%}$ \\
\hline
\end{tabular}

Hasil tanggapan siswa pada uji coba lapangan pada aspek kualitas teknis atau tampilan menunjukkan bahwa 58 orang (100\%) menyatakan "Sangat Baik" tampak pada Tabel 6.

Tabel 6. Tingkat Kecenderungan Penilaian Terhadap Aspek Kualitas Teknis/Tampilan Media Elearning menggunakan schoology Mata Pelajaran Konversi Energi Pada Uji Coba Lapangan

\begin{tabular}{|c|l|c|c|c|}
\hline No & \multicolumn{1}{|c|}{ Kategorisasi } & Rentang Skor & Frekuensi & Persentase \\
\hline 1 & Sangat Baik & $81 \% \leq X \leq 100 \%$ & 58 & $100,00 \%$ \\
\hline 2 & Baik & $61 \% \leq X \leq 80 \%$ & 0 & $0,00 \%$ \\
\hline 3 & Sedang & $41 \% \leq X \leq 60 \%$ & 0 & $0,00 \%$ \\
\hline 4 & Kurang Baik & $21 \% \leq X \leq 40 \%$ & 0 & $0,00 \%$ \\
\hline 5 & Sangat kurang & $0 \% \leq X \leq 20 \%$ & 0 & $0,00 \%$ \\
\hline \multicolumn{2}{|l|}{ Jumlah } & $\mathbf{5 8}$ & $\mathbf{1 0 0 , 0 0 \%}$ \\
\hline
\end{tabular}

Pada uji coba lapangan pada 58 siswa program studi keahlian teknik kendaraan ringan ternyata secara umum siswa menyatakan bahwa media pembelajaran yang dikembangkan Sangat Baik, dan tidak terdapat masalah yang harus diperbaiki. Dengan demikian tidak diadakan revisi IV pada tahap uji coba lapangan, yang juga berarti media e-learning menggunakan schoology telah siap untuk diuji keefektifannya.

Uji normalitas dibuat untuk mencari kenormalan dari sampel yang diteliti. Uji normalitas menggunakan rumus uji lilliefors. Setelah dilakukan perhitungan, untuk kelas eksperimen diperoleh nilai $L_{\text {hitung }}=0,136$, sedangkan $\mathrm{L}_{\text {tabel }}$ pada taraf $\alpha=0,05$ dan $\mathrm{n}=29$ adalah 0,161. Hal ini menunujukkan $\mathrm{L}_{\text {hitung }}<$ $\mathrm{L}_{\text {tabel }}$ artinya sampel berasal dari populasi yang berdistribusi normal.

Sedangkan uji normalitas nilai pretes untuk kelas kontrol diperoleh diperoleh nilai $\mathrm{L}_{\text {hitung }}=0,111$, sedangkan $\mathrm{L}_{\text {tabel }}$ pada taraf $\alpha=$ 0,05 dan $\mathrm{n}=29$ adalah 0,161. Hal ini menunujukkan $\mathrm{L}_{\text {hitung }}<\mathrm{L}_{\text {tabel }}$ artinya sampel berasal dari populasi yang berdistribusi normal. Setelah dilakukan perhitungan, untuk kelas eksperimen diperoleh nilai $L_{\text {hitung }}=0,141$, sedangkan $\mathrm{L}_{\text {tabel }}$ pada taraf $\alpha=0,05$ dan $\mathrm{n}=29$ adalah 0,161. Hal ini menunujukkan $\mathrm{L}_{\text {hitung }}<$ $\mathrm{L}_{\text {tabel }}$ artinya sampel berasal dari populasi yang berdistribusi normal.

Sedangkan uji normalitas nilai pretes untuk kelas kontrol diperoleh diperoleh nilai $\mathrm{L}_{\text {hitung }}=0,126$, sedangkan $\mathrm{L}_{\text {tabel }}$ pada taraf $\alpha=$ 0,05 dan $\mathrm{n}=29$ adalah 0,161. Hal ini menunujukkan $\mathrm{L}_{\text {hitung }}<\mathrm{L}_{\text {tabel }}$ artinya sampel berasal dari populasi yang berdistribusi normal. Berdasarkan uji normalitas kedua kelas diatas, maka dapat disimpulkan bahwa seluruh populasi data penelitian berdistribusi normal. Dari perhitungan uji homogenitas untuk nilai pretes diperoleh $\mathrm{F}_{\text {hitung }}=1,501$ sedangkan $\mathrm{F}_{\text {tabel }}$ diperoleh sebesar 3,33 dengan $\alpha=0,05$. Sehingga diperoleh $F_{\text {hitung }}<F_{\text {tabel }}$ yaitu 1,501 < 3,33, maka dapat disimpulkan bahwa data dari kedua sampel untuk pretes atau tes sebelum perlakuan mempunyai varians yang sama.Sedangkan dari perhitungan uji homogenitas untuk nilai postes diperoleh $F_{\text {hitung }}$ $=1,709$ sedangkan $\mathrm{F}_{\text {tabel }}$ diperoleh sebesar 3,33 dengan $\alpha=0,05$. Sehingga diperoleh $\mathrm{F}_{\text {hitung }}<$ $F_{\text {tabel }}$ yaitu $1,709<3,33$, maka dapat disimpulkan bahwa data dari kedua sampel untuk pretes atau tes sebelum perlakuan mempunyai varians yang sama atau homogen. $\mathbf{t}$ pretes Setelah dilakukan uji keBaikan data 
selesai maka selanjutnya dilakukan uji t pretes penelitian. Hal ini dilakukan untuk mengetahui apakah terdapat perbedaan kemampuan awal kelas kontrol dan kelas eksperiman dengan menggunakan uji $\mathrm{t}$ pretes. Berdasarkan hasil perhitungan pada diperoleh output $t_{\text {hitung }}$ sebesar $-1,385$ dan $t_{\text {tabel }}$ sebesar 1,67 pada taraf kepercayaan 95 persen. Maka diperoleh bahwa $\mathrm{t}_{\text {hitung }}<\mathrm{t}_{\text {tabel }}$ atau $-1,385<1,67$ atau dengan kata lain $\mathrm{Ha}$ ditolak. Hal ini menujukkan bahwa kemampuan awal siswa baik kelas control dan kelas eksperimen adalah cenderung sama dan tidak berbeda secara signifikan.

Ho : $\mu_{1}=\mu_{2}$

Ha $: \mu_{1}>\mu_{2}$

Keterangan :

$\mu_{1}=$ Rata-rata hasil belajar siswa yang diajar menggukan media e-learning menggunakan schoology.

$\mu_{2}=$ Rata-rata hasil belajar siswa yang diajar dengan pembelajaran konvensional.

Ho = Tidak ada perbedaan hasil belajar mesin konversi energi siswa yang diajar dengan menggunakan media e-learning menggunakan schoology dari siswa yang diajar dengan pembelajaran konvensional.

$\mathrm{Ha}=$ Ada perbedaan hasil belajar mesin konversi energi siswa yang diajar dengan menggunakan media e-learning menggunakan schoology lebih tinggi dari siswa yang diajar dengan pembelajaran konvensional.

Setelah dilakukan uji $\mathrm{t}$ pretes selesai maka selanjutnya dilakukan pengujian hipotesis penelitian dengan menggunakan uji $\mathrm{t}$ postes. Hal ini dilakukan untuk mengetahui apakah ada perbedaan hasil belajar siswa setelah dilakukan perlakuan yang berbeda. Berdasarkan hasil perhitungan pada tabel diatas diperoleh output $t_{\text {hitung }}$ sebesar 3,285 dan $t_{\text {tabel }}$ sebesar 1,67 pada taraf kepercayaan 95 persen. Maka diperoleh bahwa $t_{\text {hitung }}>t_{\text {tabel }}$ atau 3,285 >1,67 atau dengan kata lain $\mathrm{H} 0$ di tolak dan Ha diterima. Berdasarkan data-data di atas maka disimpulkan bahwa hasil belajar mesin konversi energisiswa yang diajar dengan menggunakan media e-learning menggunakan schoology lebih tinggi dari siswa yang diajar dengan pembelajaran konvensional teruji kebenarannya. Hal ini berarti hasil belajar siswa yang menggunakan media e-learning menggunakan schoology lebih tinggi dari hasil belajar siswa yang diajar dengan pembelajaran konvensional dengan efektifitas penggunaan media interaktif sebesar $80,46 \%$

\section{Pembahasan}

Produk pengembangan media elearning menggunakan schoology pada mata pelajaran mesin konversi energi merupakan materi pembelajaran yang telah dikembangkan dengan memperhatikan aspek pembelajaran dan media sebagai prinsip desain pesan pembelajaran. Penelitan pengembangan produk yang dilakukan ini diarahkan untuk menghasilkan suatu produk berupa media elearning menggunakan schoology pada mata pelajaran konversi energi Program studi keahlian teknik kendaraan ringan semester I (ganjil) yang digunakan untuk meningkatkan proses pembelajaran maupun kompetensi siswa. Oleh sebab itu proses penelitian ini dilakukan dan diawali dengan, (1) studi pendahuluan, (2) kemudian mendesain media pembelajaran, melakukan validasi produk dan melakukan revisi dan penyempurnaan berdasarkan analisis data validasi dari ahli materi, (4) ahli desain pembelajaran dan ahli rekayasa perangkat lunak yang dilanjutkan dengan uji coba perorangan, uji coba kelompok kecil, dan uji coba lapangan sehingga dihasilkan media pembelajaran yang Baik digunakan sesuai dengan karakteristik mata pelajaran dan siswa sebagai pengguna. Hal ini sejalan dengan pendapat Borg dan Gall (1983:772) pada buku Education Research an Introduction yang mengemukakan bahwa penelitian pengembangan adalah penelitian yang berorientasi untuk mengembangkan dan memvalidasi produkproduk yang digunakan dalam pendidikan.

Aspek yang direvisi dan disempurnakan berdasarkan analisis data dan uji coba serta masukan dari ahli materi, ahli desain pembelajaran, ahli rekayasan perangkat lunak dan siswa selaku pengguna media e-learning menggunakan schoology ini, bertujuan untuk menggali beberapa aspek yang lazim dalam proses pengembangan suatu produk. Variabelvariabel media pembelajaran memiliki nilai rata-rata Sangat Baik. Adapun variabel media 
pembelajaran yang dinilai meliputi keBaikan isi, penyajian, kebahasaan, pemrograman, dan kegrafikan.

Berikut hasil rangkuman persentase rata-rata hasil penilaian terhadap media elearning menggunakan schoology mata pelajaran konversi energi oleh ahli materi, ahli desain pembelajaran, ahli rekayasa perangkat lunak, uji coba perorangan, uji coba kelompok kecil dan uji coba lapangan dapat dilihat pada tabel 7. berikut ini.

Tabel 7. Rangkuman Persentase Rata-Rata Hasil Penilaian Terhadap Media E-learning menggunakan schoology Pada Mata Pelajaran Mesin Konversi Energi

\begin{tabular}{|c|c|c|c|}
\hline No & Responden & $\begin{array}{l}\text { Persentase } \\
\text { Rata-rata }\end{array}$ & Kriteria \\
\hline 1 & Ahli materi & $93,83 \%$ & Sangat Baik \\
\hline 2 & Ahli desain pembelajaran & $88,55 \%$ & Sangat Baik \\
\hline 3 & Ahli rekayasa perangkat lunak & $94,10 \%$ & Sangat Baik \\
\hline 4 & Siswa pada uji coba perorangan & $91,43 \%$ & Sangat Baik \\
\hline 5 & Siswa pada uji coba kelompok kecil & $93,63 \%$ & Sangat Baik \\
\hline 6 & Siswa pada uji coba lapangan & $97,96 \%$ & Sangat Baik \\
\hline & Rata-Rata & $93,25 \%$ & Sangat Baik \\
\hline
\end{tabular}

Beberapa kegunaan dan manfaat dalam penggunaan media e-learning menggunakan schoology pada mata pelajaran konversi energi sebagai berikut: (1) materi mudah dipahami karena konsep yang disajikan direncanakan untuk mempermudah siswa dan sistematis, (2) media e-learning menggunakan schoology memberi kesempatan siswa untuk belajar sesuai dengan kecepatan masing-masing individu, (3) belajar lebih cepat dan menarik sehingga tidak menimbulkan kebosanan karena dilengkapi dengan gambar-gambar dan animasi serta soal latihan yang bervariasi. (4) adanya kesempatan dalam menjawab soal pada waktu tes jika jawaban dianggap salah dengan tujuan agar siswa dapat memahami materi yang telah dipelajari, (5) media e-learning menggunakan schoology ini juga dapat digunakan sebagai alternatif media pembelajaran secara konvensional maupun individual.

\section{Pembahasan Hasil Penelitian Uji Keefektifan Produk}

Sebuah media bisa dikatakan Baik setelah memperlihatkan hasil yang memuaskan dalam mencapai tujuan yang telah ditentukan. Dalam hal ini, maka dilakukanlah uji coba produk pada proses pembelajaran untuk mengetahui efektifitas pembelajaran. Efektifitas media itu, didapat dari nilai hasil belajar siswa. Miarso (2011:536) indikator yang dapat digunakan untuk menentukan efektivitas dalam proses pembelajaran adalah : (a) pengorganisasian materi yang baik, (b) komunikasi yang efektif, (c) penguasaan dan antusiasme terhadap materi pelajaran, (d) sikap positif terhadap siswa, (e) pemberian nilai yang adil, (f) keluwesan dalam pendekatan pembelajaran, dan $(\mathrm{g})$ hasil belajar siswa yang baik.

Dari hasil pengolahan data penelitian yang dilakukan, terdapat perbedaan hasil belajar mata pelajaran mesin konversi energi antara siswa yang dibelajarkan dengan menggunakan media e-learning menggunakan schoology dan siswa yang dibelajarkan dengan tanpa menggunakan media e-learning menggunakan schoology yaitu rata-rata hasil belajar mesin konversi energi siswa yang dibelajarkan dengan menggunakan media e-learning menggunakan schoology lebih tinggi yaitu sebesar 80,46\% dibandingkan dengan siswa yang dibelajarkan tanpa menggunakan media e-learning menggunakan schoology yaitu sebesar $71,72 \%$. Dari data ini membuktikan bahwa penggunaan media e-learning menggunakan schoology lebih Baik dalam meningkatkan kompetensi dan pengetahuan siswa pada mata pelajaran mesin konversi energi daripada tanpa menggunakan media e-learning menggunakan schoology. Hasil penelitian ini sejalan dengan Ligin (2012) dalam pengembangan media e-learning menggunakan schoology pada mata pelajaran Geografi menggunakan perangkat lunak program Macromedia Flash professional 8.0 membuktikan bahwa media pembelajaran intraktif memiliki keaktifan sebesar 82,55\% lebih tinggi dari pada keefektifan media pembelajaran buku teks sebesar $77,84 \%$. Dalam 
pengembangan digunakan perpaduan model media e-learning menggunakan schoology dari Borg and Gall dan Dick and Carey.

Johnson (2012) dalam pengembangan media e-learning menggunakan schoology pada mata pelajaran Matematika menggunakan perangkat lunak program Macromedia Flash Professional 8.0 membuktikan bahwa media elearning menggunakan schoology memiliki keefektifan sebesar $70.73 \%$ lebih tinggi dari pada keefektifan menggunakan media pembelajaran buku teks sebesar $60,32 \%$.

\section{PENUTUP}

Berdasarkan rumusan, tujuan, hasil dan pembahasan penelitian pengembangan media elearning menggunakan schoology yang dikemukakan sebelumnya maka dapat disimpulkan sebagai berikut:

(1) Hasil validasi dari ahli materi, ahli desain pembelajaran dan ahli media pembelajaran terhadap media e-learning menggunakan schoology pada mata pelajaran konversi energi yang dikembangkan dengan

AECT. (1977). Definisi teknologi pendidikan (satuan tugas definisi \& terminologi AECT). Jakarta. Rajawali.

AECT. (2004). Definition and Terminology Committee document \#MM4.0 June 1, 2004 [Online] Tersedia: http://www.indiana.edu/ molpage /Meanings\%20of\%20ET 4.0.pdf, diakses tanggal 15 September 2015

Ahmadi dan Supriyono. (2008). Psikologi Belajar. Jakarta: PT. Rineka Cipta.

Borg, W. \&V Gall, M.D. (1983). Educational research. An introduction ( $4^{\text {nd }}$ ed). New York \& London: Longman.

Gagne, Robert M and Briggs, Leslie J. (1979). Principles of Instructional Design $\left(2^{\text {nd }}\right.$ $E d$.). New York: Holt, Rinehart and Winston.

Hamalik, Oemar. (2003). Media Pendidikan. Bandung: PT Aditya Bakti.Soekartawi (2007:4)

Johnson David W and Roger T. Johnson. (2002). Cooperative Learning Methode: A Meta-Analysis. Journal of Research in Education. http://www.eeraonline.org/ journal/files/2002/JRE_2002_01_DWJ ohnson. pdf
Software Macromedia Flash Professioanl 8.0 menunujukkan bahwa keseluruhan rata-rata dikategorikan "Sangat Baik" setelah dilakukan beberapa revisi sehingga media tersebut dapat digunakan untuk uji coba selanjutnya. Hasil validasi dari uji coba perorangan, uji coba kelompok kecil, dan uji coba lapangan terbatas terhadap media yang dikembangkan dengan Software Macromedia Flash Professioanl 8.0 termasuk dalam kategori "Sangat Layak" sehingga dapat diterima dan Baik digunakan sebagai media belajar.

(2) Penggunaan media e-learning menggunakan schoology lebih "efektif" dapat meningkatkan hasil belajar bila dibandingkan dengan menggunakan media buku teks, media e-learning menggunakan schoology memiliki keefektifan sebesar $80,46 \%$ lebih tinggi dari keefektifan media pembelajaran buku teks sebesar $71,72 \%$.

\section{DAFTAR PUSTAKA}

Johnson, D.W., Johnson, R.T. \& JohnsonHolubec, E.J.(2003). Cooperation in the Classroom. Bandung: Alfabeta.

Miarso, Yusufhadi. dkk. (2011). "Media Pendidikan Teknologi Komunikasi Pendidikan. Jakarta: Rajawali.

Musfiqon. (2012). Pengembangan Media Belajar Dan Sumber Belajar. Jakarta: Prestasi Pustakakarya. Munir (2010: 202)

Pribadi, Benny A. (2009). Model Desain Sistem Pembelajaran. Jakarta: Dian Rakyat.

Pupuh dan Sobry. (2007). Strategi Belajar Mengajar Melalui Penanaman Konsep Umum \& Konsep Islami. Bandung: Refika Aditama.

Reigeluth, M Charles. (1983). InstructionalDesign Theories and Models, An Overview of their Current Status. New jersey: London.

Seells dan Richey. (1996). Instructional technology (Mahasiswa S2 IKIP Malang Terjemahan). IKIP Malang

Sudjana, Nana. (2004). Penilaian Hasil Proses Belajar Mengajar. Bandung : Rosdakarya.

Sudjana. (2002). Metoda Statistika. Bandung: Tarsito.

Sudjana. (2005). Media Pengajaran. Bandung : Sinar Baru Algensindo 